\title{
Beijing 1987: China's coming-out party
}

\section{Two decades ago, Deng Xiaoping welcomed nations to an international meeting in Beijing. Mohamed Hassan recalls how China's leaders set out their plans for the nation to rejoin the world's scientific elite.}

The memory is still fresh. On 12 September 1987, I flew into a Beijing airport that comprised a few badly maintained structures, no larger than a small provincial airfield. All around was peeling paint and dim lighting, no signs, no assistance and an anxious wait for luggage.

The drive from the airport was another eyeopener. The road we took was poorly paved. Street lighting was sporadic. A smattering of cars, mainly Japanese-made, had to make room for bicycles, wheelbarrows and the occasional donkey cart. Beijing was a busy, even frenetic place. It was certainly well cared for. But it was impoverished.

The Beijing from the window of my car was the image of China in the West. Yet, over the next five days, the idea of China as a povertystricken backwater, unable to harness new ways of learning and ultimately modernity, would be tested and changed forever.

As I and the other delegates were about to discover, China's most prominent officials and scientists all agreed that science and technology would be a key element in the country's plans to re-emerge as a global power. As one of my colleagues, MGK Menon, former chief scientific adviser to India's late prime minister Indira Gandhi, recalls today: "the state of science in China was a welcome surprise but largely because so little was known about it."

\section{Drawn together}

I was then starting my career at TWAS, then known as the Third World Academy of Sciences and the brainchild of the Pakistani theoretical physicist Abdus Salam. Salam had lured me to the academy from the University of Khartoum in Sudan, where I was a professor of mathematics, specializing in modelling the formation and the movement of desert dust and sand.

Salam knew China well; his contacts were at the highest levels. He also knew that China's leadership wanted both to open up to the West and to have a leading role for the developing nations of the South. So it was no surprise for me to learn that our second general conference would in effect become China's coming-out party - an opportunity for the country to show itself off to the world (both North and South) and a chance for enterprising scientists and policymakers from the developing countries to learn from - and do business with - Beijing.

Salam had other reasons for wanting to work with China. He was a candidate for the job of running UNESCO, the United Nations Educational, Scientific and Cultural Organization. As a Nobel prize-winning professor at Imperial College London, Salam had little difficulty accessing the levers of power in the Anglophone world. But to secure the UNESCO post he needed the backing of countries elsewhere. Getting a nod from a permanent member of the UN Security Council, such as China, would certainly help.

\section{China anew}

The opening session took place in the Great Hall of the People two days later on 14 September. There were more than 150 participants from 50 countries, joined by an equal number from China. Given that this was a rare example of China putting its science on display, interest from the Western scientific community was high. International organizations represented in Beijing included the then International Council of Scientific Unions (ICSU), headed by Julia Marton-LaFèrre, the International Foundation for Science (IFS), the American Association for the Advancement of Science (AAAS) and the Science Council of Japan.

The Chinese Academy of Sciences, an institution that is key to understanding science in modern China, was our host. Whereas, in Western countries, government ministries, research funding bodies and scientists operate
"The state of science in China was a welcome surprise but largely because so little was known about it." (mostly) independently of each other. In China (as in Russia), all three of these functions are rolled into a single state-run and state-funded academy of sciences. The Chinese academy, which was established just two months after the Communist takeover in 1949, had grown substantially in size and impact over the next two decades. However, the assault on intellectuals during the 10-year Cultural Revolution severely put back the academy's work.

The scars of this period had clearly not yet healed for many of the Chinese speakers at the 1987 conference. In his opening address, Zhou Guangzhao, then president of the Chinese Academy of Sciences, described the Cultural Revolution as a "disaster" for China. Similarly, Zhao Ziyang, general secretary of the Communist Party, said that bullying and humiliation had characterized the Cultural Revolution.

China's leader, Deng Xiaoping, later told Salam that if China did eventually join the ranks of developed nations, it would never forget its history and where it came from: that it would always see itself as a developing country first and foremost. But that said, out of the embers of the Cultural Revolution, it harboured larger ambitions.

Too often, the main message coming out of conferences on science and technology in developing countries was (and still is) one of inadequate salaries, low standards of research and development, poor working conditions and either political apathy or excessive political interference. Beijing 1987 could have been the same. However, our hosts were determined to show that they would not be defined by the past.

We learnt from the opening talks that, in 1949 , China, with a population of nearly 550 million, had just 50,000 people recorded as working in science and technology in some 30 scientific institutes. But by 1985 , the country had more than 10 million people working in almost all fields of science and technology, including 300,000 active researchers. The Chinese Academy of Sciences alone had 80,000 scientists working in more than 120 research institutes. The academy system was complemented by a rapidly growing system of higher education consisting of 2 million students in more than 1,000 universities.

We also learnt that China's scientists had been busy pushing the envelope in a diverse set of research fields. Among other achievements, they had synthesized bovine insulin, carried out research into low-temperature, high-conducting materials, launched 19 satellites and developed an extensive nationwide remotesensing system. In agriculture, China had eliminated the wheat-rust fungus and created hybrid rice varieties, allowing improved crop yields. In health care, vaccines had led to significant reductions in the incidence of diseases such as diphtheria, scarlet fever and polio. 


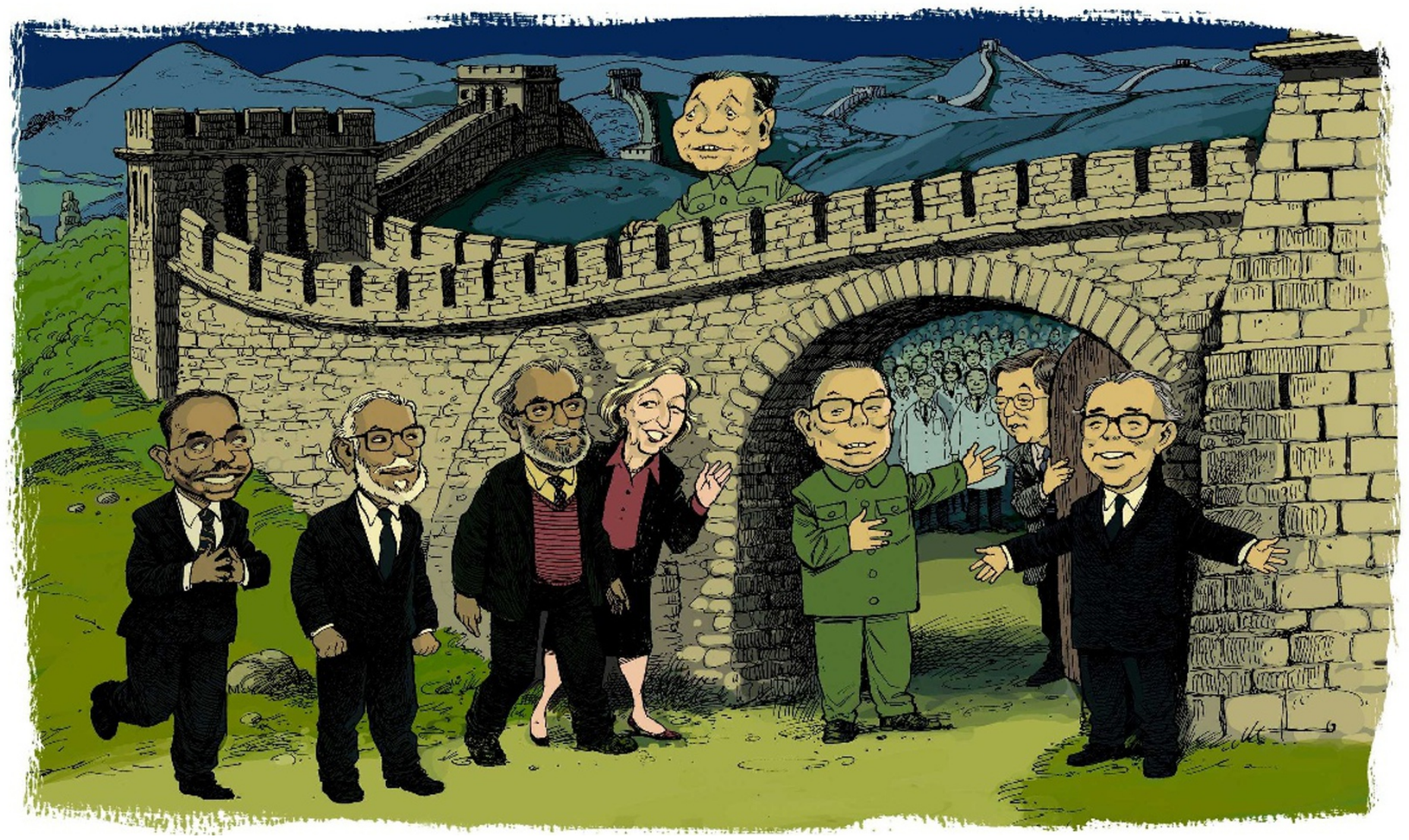

Listening to the presentations and observing China's scientists, it became clear that this kind of progress was different from that taking place in other Communist countries - especially the Soviet Union. Unlike former Soviet Russia, for example, China had no problems in acknowledging that it would need access to Western science and technology to innovate. At the time of the conference, an estimated 100,000 students from China had studied or worked abroad (mostly in Western countries) and then returned home to help build their nation's infrastructure. This number is now in excess of one million.

Finally, we learnt that China, which had begun to open the door of scientific exchange with both developed and developing countries, was eager to collaborate with partners in a broad range of fields. To facilitate this, Chinese officials announced that they would be hosting a TWAS-China field office inside the Chinese Academy of Sciences.

This was a truly transformational moment. China was telling us that it was no longer alone in science, that it would welcome opportunities to become part of the international scientific community and that it was eager to join with others both to enhance its own capabilities and to help address critical global challenges in both science and society. Biotechnology, materials science, particle physics and space science were about to get a new major partner, and both China and the rest of the world would benefit as a result.

\section{Back to the future}

I returned to China in October 2003 to celebrate TWAS's 20th anniversary. My journey began in Trieste and ended at Beijing's international airport, just as it had 15 years earlier. The opening ceremony, just as before, was held in the Great Hall of the People.

I may have followed the same roads to the same places in Beijing, but so much else had changed. The airport was a gleaming new state-of-the-art facility and one of the biggest and busiest airports in the world. The treelined avenues that led from the airport to the city centre were jammed with automobiles and taxis, and framed by sleek apartment houses, office buildings and commercial establishments. Enormous holes in the ground, shadowed by large construction cranes overhead, foretold of larger structures to come, including the venues for the 2008 Olympics.

$\mathrm{Hu}$ Jintao, China's president, spoke at the opening ceremony in front of 3,000 people. The audience consisted not just of scientists and political leaders from around the world, but also of many young Chinese students who filled the outer reaches of the great hall. Earlier that day, Hu had congratulated China's first astronaut, Yang Liwei, who had just returned home after completing a 21-hour, 14orbit journey around Earth. The space flight, President Hu observed, constituted "another important step for the Chinese people scaling to the summit of world science and technology".

As I listened to President $\mathrm{Hu}$ and peered at the audience beyond the podium, I could not help but think that one of the most important first steps
irth as an international scientific powerhouse took place in the same hall in 1987. The promise of modern science and technology in China that I had first glimpsed 15 years ago had been fulfilled.

Mohamed Hassan is the executive director of TWAS, the academy of sciences for the developing world in Trieste, Italy. He was a participant at the academy's second general conference, held in Beijing from 14-18 September 1987. e-mail:mhassan@twas.org

For more Meetings that Changed the World, see www.nature.com/nature/focus/meetings 